\title{
Design and Evaluation of the PV Simulator with Modified P\&O Algorithm
}

\author{
Ersagun Kürşat Yaylaci ${ }^{1}$, Mohammad Al Msalma ${ }^{2}$, Novruz Mammadli ${ }^{3 *}$ \\ ${ }^{1}$ Karabuk University, Faculty of Engineering, Departmant of Electrical and Electronics Engineering, Karabuk, Turkey, (ORCID: 0000-0003-0358-5617), \\ ekyaylaci@karabuk.edu.tr \\ ${ }^{2}$ Karabuk University, Faculty of Engineering, Departmant of Electrical and Electronics Engineering, Karabuk, Turkey, (ORCID: 0000-0002-3470-2540), \\ moh.almsalma@gmail.com \\ $3^{3^{*}}$ Karabuk University, Faculty of Engineering, Departmant of Electrical and Electronics Engineering, Karabuk, Turkey, (ORCID: 0000-0003-2886-0080), \\ novruz31198@gmail.com
}

(1st International Conference on Applied Engineering and Natural Sciences ICAENS 2021, November 1-3, 2021)

(DOI: 10.31590/ejosat.1012151)

ATIF/REFERENCE: Yaylac1, E.K., Al Msalma, M. \& Mammadli, N. (2021). Design and Evaluation of the PV Simulator with Modified P\&O Algorithm. European Journal of Science and Technology, (28), 933-939.

\begin{abstract}
In this study, a photovoltaic simulator simulates the behaviour of a photovoltaic system is designed. A DC-DC buck type converter is used to realize the photovoltaic simulator. The photovoltaic simulator gives researchers, manufacturers, and university laboratories the opportunity to easily test their systems under variable irradiances and temperatures without the need to wait until weather conditions become proper to study. The designed photovoltaic simulator is verified in terms of the I-V and P-V characteristics of the photovoltaic panel by comparing it with the photovoltaic model of the MATLAB/Simulink. A DC-DC boost converter is connected to the designed photovoltaic simulator to be able to maximum power point tracking studies. Moreover, perturb and observe method used to get maximum power from the photovoltaic panel is modified to prevent some deficiencies of the classical one. The perturb and observe method and modified perturb and observe method are applied to both the photovoltaic model of Simulink and the designed photovoltaic simulator. Thereby, the developed method is also verified by the maximum power point tracking algorithms. Also, it is proved with the simulation result that the modified perturb and observe method extracts more energy than the classic one from the photovoltaic power.
\end{abstract}

Keywords: Photovoltaic Simulator, Maximum power point tracking, Perturb and observe algorithm, MATLAB.

\section{PV Simülatörün Tasarımı ve Geliştirilmiş P\&O Algoritmasıyla Değerlendirilmesi}

$\ddot{O} \mathbf{z}$

Bu çalışmada, fotovoltaik sistemin davranışını simüle eden fotovoltaik simülatör tasarlanmıştır. Fotovoltaik simülatörü gerçekleştirmek için DC-DC buck tipi dönüştürücü kullanılmıştır. Fotovoltaik simülatör, araştırmacılara, üreticilere ve üniversite laboratuvarlarına, hava koşullarının çalışmaya uygun hale gelmesini beklemeye gerek kalmadan sistemlerini değişken ışınımlar ve sıcaklıklar altında kolayca test etme firsatı verir. Tasarlanan fotovoltaik simülatör, fotovoltaik panelin I-V ve P-V özellikleri açısından MATLAB/Simulink'in fotovoltaik modeli ile karşılaştırılarak doğrulanmıştır. Maksimum güç noktası takibi çalışmaları yapabilmek için tasarlanan fotovoltaik simülatöre DC-DC boost dönüştürücü bağlanmıştır. Ayrıca fotovoltaik panelden maksimum güç elde etmek için kullanılan DeğiştirGözle yöntemi, klasik Değiştir-Gözle yönteminin bazı eksikliklerini gidermek için değiştirilmiştir. Değiş̧tir-Gözle yöntemi ve geliştirilmiş Değiştir-Gözle yöntemi hem Simulink'in fotovoltaik modeline hem de tasarlanan fotovoltaik simülatöre uygulanmıştır. Böylece geliştirilen yöntem maksimum güç noktası izleme algoritmaları ile de doğrulanmıştır. Ayrıca geliştirilmiş Değiştir-Gözle yönteminin fotovoltaik güçten klasik Değiştir-Gözle yöntemine göre daha fazla enerji çektiği simülasyon çalışmaları ile kanıtlanmıştır.

Anahtar Kelimeler: Fotovoltaik simülatör, Maksimum güç noktası takibi, Değiştir-Gözle algoritması, MATLAB.

\footnotetext{
* Corresponding Author: novruz31198@gmail.com
} 


\section{Introduction}

The environmental concern because of the fossil fuel-based energy production tends to the researchers to investigate renewable energy sources (RES) (Delihasanlar et al., 2019). It is known that the PV energy extracted in one day from the earth can be enough for the total energy demands of one year (S. Hiwale et al., 2014).

The power extracted from PV panels highly depends on the irradiation and temperature values. Moreover, the maximum power for each irradiation and temperature value is a unique value for PV panels. It is called maximum power point (MPP) in the literature. A method known as maximum power point tracking (MPPT) should be used to operate the PV at MPP. The MPPT studies require the test conditions for the PV panels, and test conditions should not be depended on the climatic effects. It can be, of course, possible when the PV simulator (PVS) is used.

As the photovoltaic industry spreads, the need for testing new devices and technologies are increasing. Since the photovoltaic systems depend on temperature and irradiance, testing systems become so hard, especially during the winter. Another factor is the big size of the solar panels, making it challenging to test massive projects because it requires extensive areas for the solar arrays. In short, the ability to test systems under different situations is nearly impossible in normal conditions. As a result that, the need for devices that simulate the behaviour of PV arrays arose and became a must.

As a response to the need for PVS, a few companies have designed high-efficient PVS devices. But the problem is that the PV simulators designed by the big companies have a high cost. Creating a low-cost PVS with high efficiency that gives the small institutions and researchers the ability to test their systems without needing to purchase such high-cost devices can be very useful.

A new and cheap method of making a PVS is using lightemitting diodes (LEDs) as in (Tsuno et al., 2008), (Watjanatepin \& Sritanauthaikorn, 2021). Another alternative way to get the PV cells' behaviour is to use some mathematical models proposed in the literature (Rasheed et al., 2021), (Yaqoob et al., 2021), (Tamrakar et al., 2015). The single diode model is one of the widespread methods, and there are different types of models of the single diode model in (Duc et al., 2020). Also, the two diode model is prevalent, but it is very complex to implement; however, its accuracy is more than a single diode model (Ahmad et al., 2016).

The other important issue is the MPPT algorithms for the PV systems. During the last decades, taking into account technological development, various studies have reviewed multiple MPPT algorithms (Berrera et al., 2009), (Motahhir et al., 2020). Considering those methods, one of the most common algorithms for the MPPT is the Perturb and Observe (P\&O) algorithm (Abdel-Salam et al., 2020), (Farhat et al., 2016). Many studies offer different methods to improve efficiency in $\mathrm{P} \& \mathrm{O}$ algorithms. In (Amrouche et al., 2007), the Artificial Neural Networks is used to reduce the disadvantages of the P\&O method. In (Boukezata et al., 2016), a modified fuzzy logic control based on the $\mathrm{P} \& \mathrm{O}$ method is offered to test fast irradiance changing conditions

In this study, a PVS realized by a DC-DC buck converter that simulates the behaviour of a PV system is designed. The designed
PVS is tested in terms of the I-V and P-V characteristics of the PV panel by comparing it with the PV model of the MATLAB/Simulink. Furthermore, the P\&O method used to get maximum power from the PV panel is modified to prevent some deficiencies of the classical one. The P\&O and modified P\&O (MP\&O) methods are applied to both the PV model of Simulink and the designed PVS.

\section{Material and Method}

\subsection{Modelling of $P V$ panel and array}

Fig. 1 is utilized for making PV array and aimed to take into account real-time computational processing features of the simulator and the dynamic precision of the model in this research. With the help of Kirchhoff's law (KCL), the output current IPV can be calculated as in Eq. (1).

$$
I_{P V}=I_{p h}-\frac{V_{d}}{N_{s} R_{p}}-I_{d}
$$

where Id and Vd are the turn-on current and voltage of the diode, Iph is the photocell current, Rp is the parallel resistance of PV cell, Ns is the number of series PV cells VPV is the voltage of PV.

The PVS is designed to simulate the PV panel and the changes in temperature and irradiance, which are the most significant parts of the study. Based on the values of irradiance and temperature given, the PVS should estimate the new behaviour of the panel, the new I-V and P-V characteristics curves and provide the proper output values.

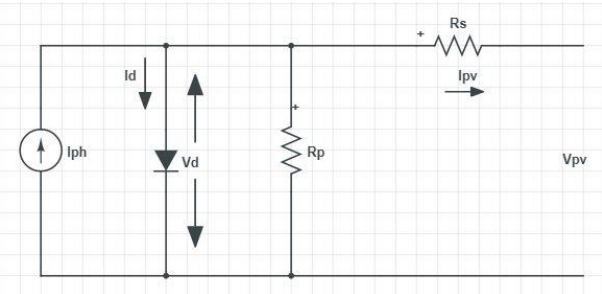

Fig. 1. Equivalent circuit of the PV cell

\subsection{Selection of PV Array}

The electrical specifications of the selected PV panel to be simulated in this study is given in Table 1.

\subsection{Block Diagram of the System}

The PVS will be based on a current feedback system where the output voltage at the load will be measured and fed back to a microcontroller. The microcontroller will define which value of current is needed as a reference based on the I-V characteristics of the solar panel. After determining the reference value, it will be fed to the system, and the load current will be subtracted from it. After passing the error signal from the PID controller, the system will be able to give the duty ratio needed at the output. Fig. 2 shows the block diagram of the system. The system will be consisting of a Buck converter as a DC-DC converter, PWM generator, PID controller, and a MATLAB function working as a microcontroller. 
Table 1. Selected solar panel features

\begin{tabular}{l|c}
\hline Module & $\begin{array}{l}\text { Bosch Solar Energy c-Si P72 } \\
\text { NA22126 280Wp }\end{array}$ \\
\hline Maximum Power & PMP $=280 \mathrm{~W}$ \\
\hline Open Circuit Voltage & $\mathrm{VOC}=45.1 \mathrm{~V}$ \\
\hline Voltage at MPP & $\mathrm{VMP}=35.9 \mathrm{~V}$ \\
\hline Short Circuit Current & $\mathrm{IMC}=8.34 \mathrm{~A}$ \\
\hline Current at MPP $=7.8 \mathrm{~A}$ \\
\hline
\end{tabular}

Fig. 2 Block diagram of the system

\subsection{Buck Converter Design}

In the basic Buck Converter circuit, the switching frequency value is selected as $40 \mathrm{kHz}$, the input voltage is $90 \mathrm{~V}$, and the $\mathrm{L}, \mathrm{C}$ and RL values are found according to the values at the maximum power using Eq. 2-Eq. 5. The values of the Buck converter parameters are shown in Table 2 (Hart, 2010), (Kazimierczuk, 2008).

$$
\begin{gathered}
R_{L}=V_{m p} / I_{m p} \\
r_{c m a x}=\Delta V_{o} / \Delta i_{L} \\
L=\left[R_{L}(1-D)\right] / 2 f \\
C=D /\left(2 f r_{\text {cmax }}\right) \\
\eta=P_{\text {OUT }} / P_{I N}
\end{gathered}
$$

where $\mathrm{RL}$ is load resistance, $\mathrm{V}_{\mathrm{mp}}$ is the voltage at the maximum power point, $\mathrm{I}_{\mathrm{mp}}$ is current at the maximum power point, $\mathrm{rcmax}$ is maximum equivalent series resistance (ESR) for $\mathrm{C}$, $\Delta \mathrm{V}_{\mathrm{o}}$ is output voltage ripple, $\Delta \mathrm{i}_{\mathrm{L}}$ is inductor current ripple, $\mathrm{L}$ is inductor value, $\mathrm{D}$ is the duty cycle, $\mathrm{f}$ is sample frequency, $\mathrm{C}$ is capacitor value, $\eta$ is efficiency, $P_{\text {OUT }}$ is the output power, $P_{I N}$ is the input power.

Table 2. Parameters of Buck Converter

\begin{tabular}{l|c}
\hline TOPOLOGY & DC-DC BUCK CONVERTER \\
\hline Frequency & $\mathrm{f}=40 \mathrm{kHz}$ \\
\hline Input Voltage & $\mathrm{Vs} 1=90 \mathrm{~V}$ \\
\hline Capacitor & $\mathrm{C} 1=218.67 \mu F$ \\
\hline Inductor & $\mathrm{L} 1=35.78 \mu H$ \\
\hline Resistor & $\mathrm{RL} 1=4.6 \Omega$ \\
\hline
\end{tabular}

\subsection{Gathering Up the PV Simulator}

After completing the design of the Buck converter, the design of the overall system starts. The PWM generator block from MATLAB is used, and its frequency is set to be $40 \mathrm{kHz}$.
The PID controller block from MATLAB is used, and the values of $\mathrm{Kp}, \mathrm{Ki}$ and $\mathrm{Kd}$ are found as 5, 1, 0.2, respectively.

For simulation purposes, instead of using a microcontroller, a MATLAB function block is used. Then the mathematical formulas of the practical single diode model are coded in it, and the effects of irradiation and temperature changes are considered. The resulting graphs in Fig. 3 are very close to the real $\mathrm{I}-\mathrm{V}$ and $\mathrm{P}-\mathrm{V}$ characteristics with less than $0.3 \%$ error value.

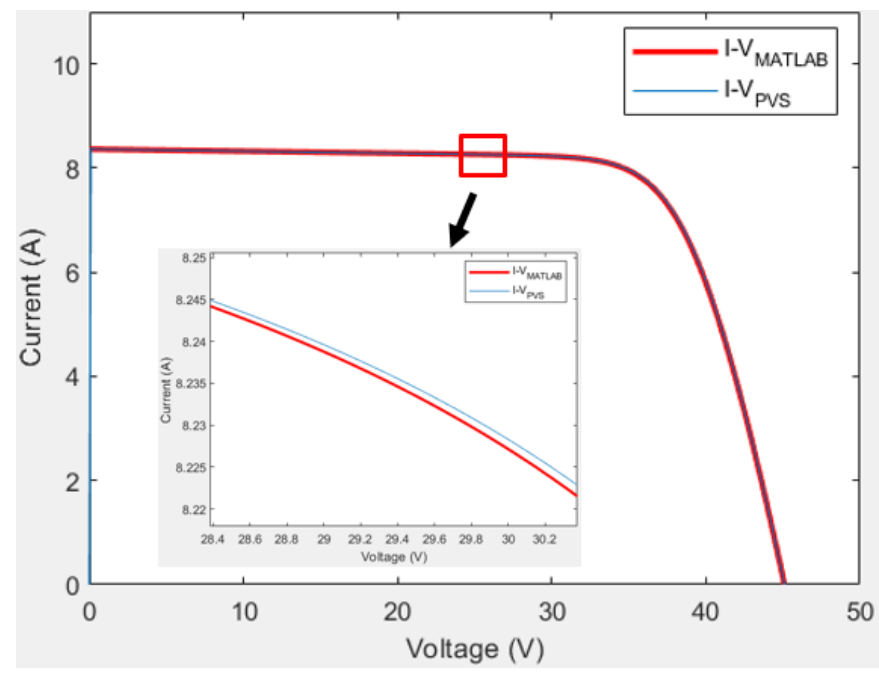

(a)

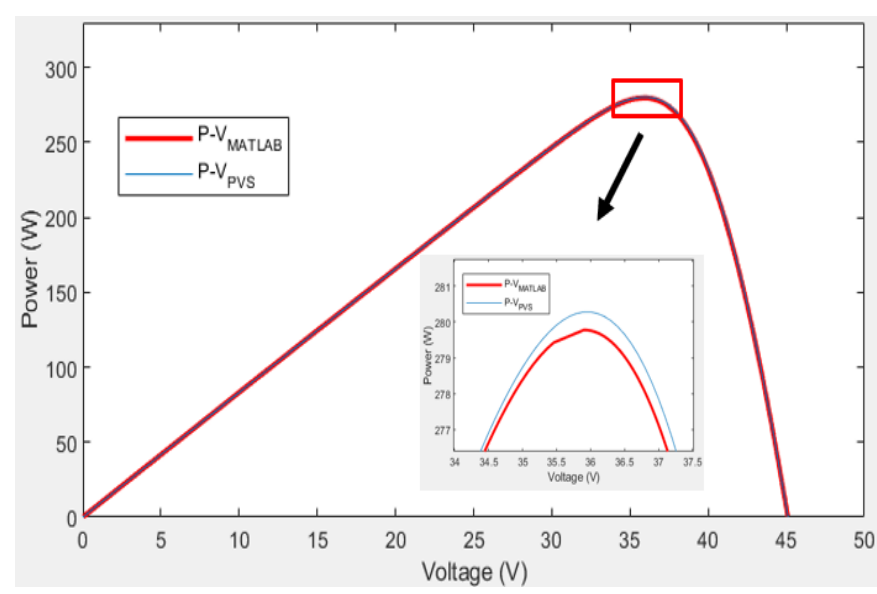

(b)

Fig. 3 Test Results of a) I-V Characteristics, b) P-V Characteristics

\subsection{Design of Boost Converter}

For designing a PV system, a DC-DC converter is very important and there are many comparative studies of these converters (Palanisamy et al., 2019), (Osmani et al., 2021), (Ettappan et al., 2021). In this paper, the boost converter is used as an interface between the PV panel and load in order to provide the ability to extract the maximum power from the panel and feed it to the load.

The switching frequency of the Boost converter is $40 \mathrm{kHz}$. The input voltage will vary since the PV array will give different voltage output based on the impedance connected to its terminals. The behaviour of the panel under the standard conditions is considered, and the Boost converter is designed to give the needed output to get the MPP. So, the input voltage will be taken as $35.9 \mathrm{~V}$, 
and the Boost converters duty cycle at the MPP determined as $70 \%$. The load resistor is determined based on Eq. 7, L and C values are found based on Eq. 8, 9 and with a ripple of $100 \mathrm{~mA}$ and $100 \mathrm{mV}$, respectively. The values of the Buck converter parameters are shown in Table 3. (Hart, 2010).

$$
\begin{gathered}
R_{L}=V_{o}^{2} / P \\
C=V_{o} D /\left[\Delta V_{o}(1-D) R_{L} f\right] \\
L=D(1-D)^{2} R_{L} / 2 f
\end{gathered}
$$

where $\mathrm{P}$ is the panel power, $V_{o}$ is the output voltage.

Table 3. Parameters of Buck Converter

\begin{tabular}{l|c}
\hline TOPOLOGY & DC-DC BOOST CONVERTER \\
\hline Frequency & $\mathrm{f}=40 \mathrm{kHz}$ \\
\hline Input Voltage & $\mathrm{Vs} 2=35.9 \mathrm{~V}$ \\
\hline Capacitor & $\mathrm{C} 2=409.5 \mu F$ \\
\hline Inductor & $\mathrm{L} 2=40.27 \mu H$ \\
\hline Resistor & $\mathrm{RL} 2=51.14 \Omega$ \\
\hline Input Capacitor & $\mathrm{Cin}=1000 \mu F$ \\
\hline
\end{tabular}

\subsection{P\&O Algorithm}

Perturb and Observe (P\&O) is one of the most popular MPPT algorithms (Elgendy et al., 2012). This algorithm's working principle takes continuous $\mathrm{V}_{\mathrm{PV}}$ and $\mathrm{I}_{\mathrm{PV}}$ samples to find the power and compares them with the previous power values. Voltage is increased or decreased considering the change in power. This process continues until the system reaches the MPP.

\subsection{Modified P\&O Algorithm}

The flowchart illustrated in Fig. 4 shows the modified P\&O method where the new variable step algorithm is implemented. In this paper, a variable step $\mathrm{P} \& \mathrm{O}$ method is suggested to improve the performance of the MPPT algorithm. One of the best advantages of the modified algorithm is that it takes a shorter time to reach MPP, whereas the classic $\mathrm{P} \& \mathrm{O}$ algorithm, which can not include variable step function, took much more time to achieve MPP.

Another critical issue is that the classic $\mathrm{P} \& \mathrm{O}$ method has an oscillation at the MPP. It is prevented in the offered method. To eliminate this problem value of the duty cycle must be constant on the MPP; thus, the latest value of the duty cycle will be $\mathrm{D}(\mathrm{k})$, the previous one $\mathrm{D}(\mathrm{k}-1)$ and the prior one $\mathrm{D}(\mathrm{k}-2)$. The task in this algorithm is to catch when $\mathrm{D}(\mathrm{k})$ and $\mathrm{D}(\mathrm{k}-2)$ are equalized, so the duty cycle value will be constant after this equation. But there is another important problem: function first has to decide whether $\mathrm{D}(\mathrm{k}-2)$ or $\mathrm{D}(\mathrm{k}-1)$ is closer to MPP. To resolve it, the function has to compare the actual power value with the previous one and based on that; the duty cycle value will be assigned.

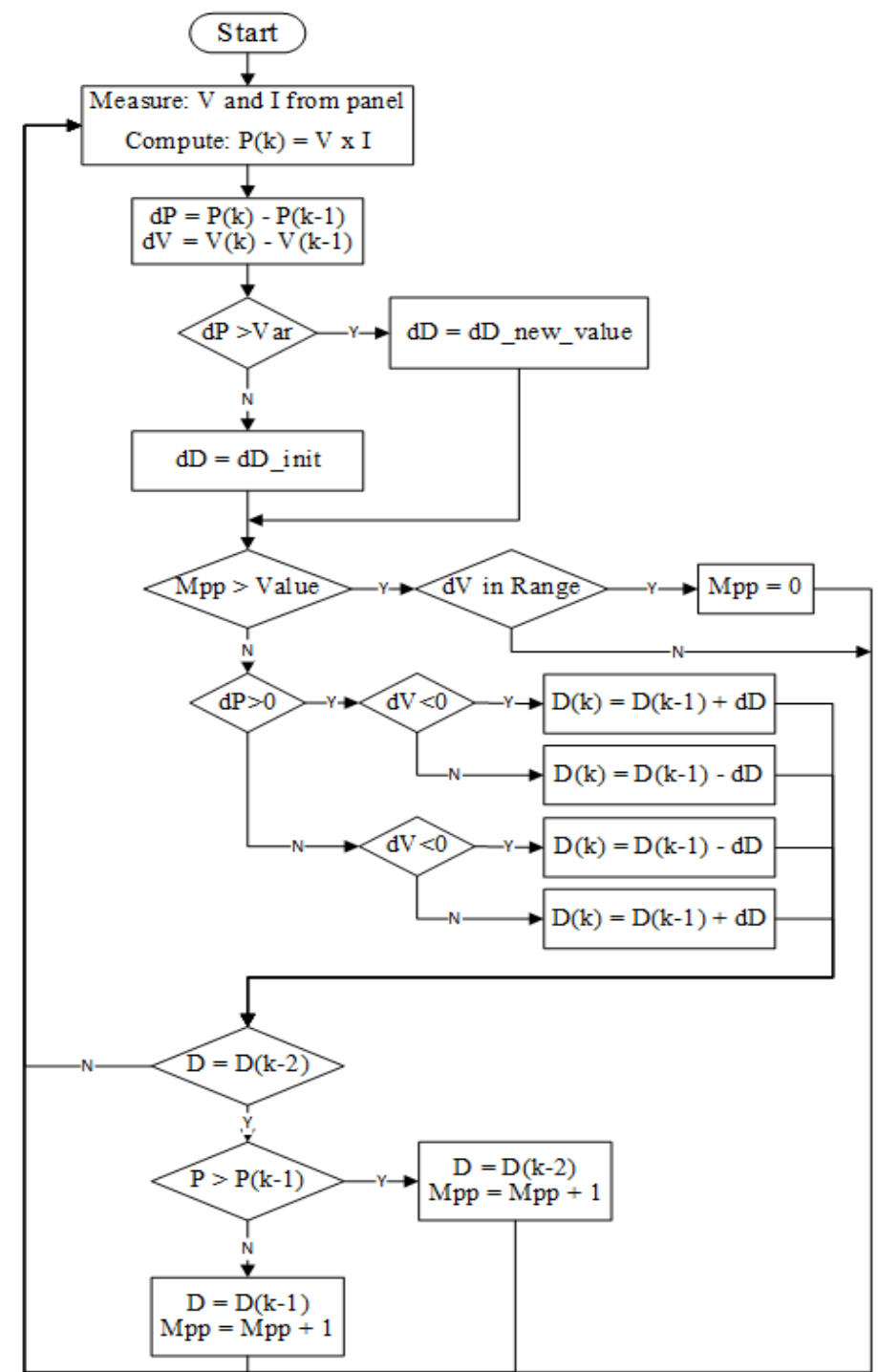

Fig. 4 Flowchart of Modified P\&O Algorithm

After fixing the value of the duty cycle to a constant value, the function has to check in every change that if there will be any significant increase or decrease in the voltage. Whenever a significant change happens, the duty cycle must quit its constant value and start to change to capture the new MPP related to the new irradiance value.

\subsection{Test Methodology}

The PV array of MATLAB is also used to test the designed PVS, as shown in Fig. 5.
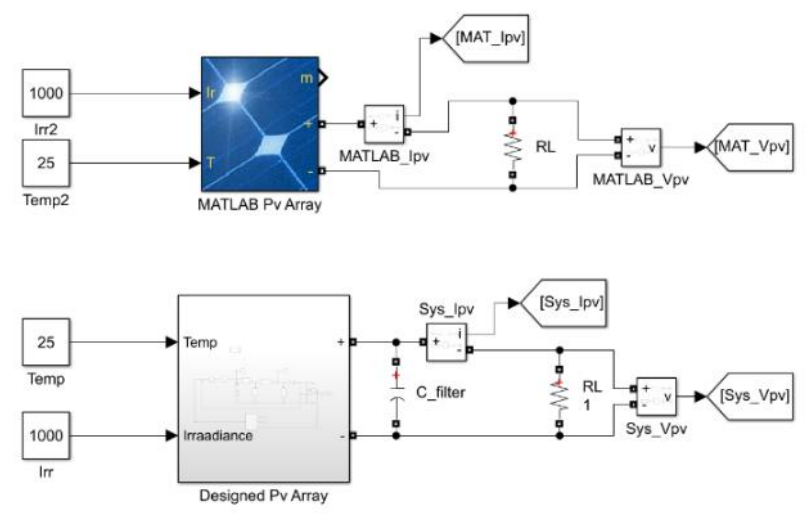

Fig. 5 MATLAB and PVS Circuits 
The irradiance to be applied to the systems is changed as given in Fig. 6.

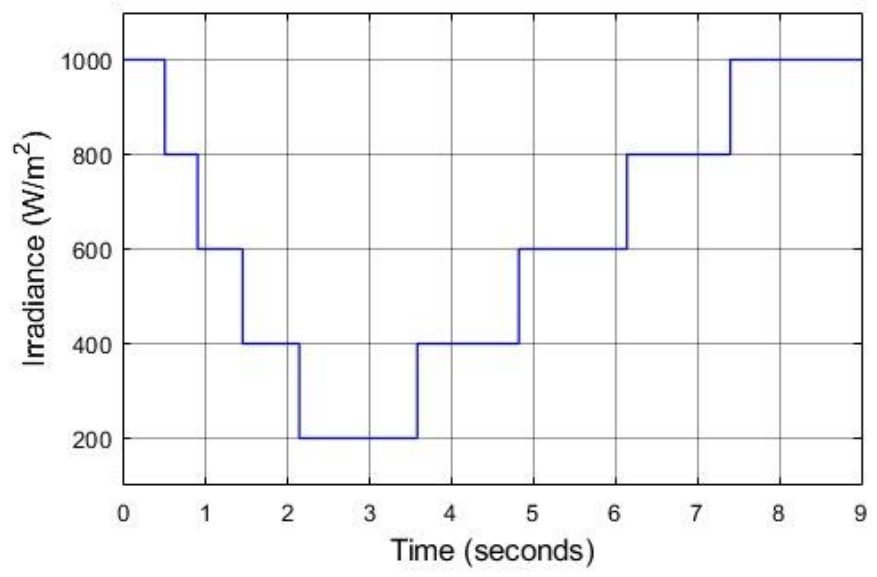

Fig. 6 Irradiance Test Signal

\section{Results and Discussion}

\subsection{Results of PV Simulator Device}

The PVS is tested for $1000 \mathrm{~W} / \mathrm{m} 2$, then the results are compared with the results got from the MATLAB PV model. The results of the two systems are illustrated in Fig. 7.

As a result, the PVS is working very well. From the figures, it is seen that it takes the system time until it settles in the desired value. That is because the capacitor and the inductor inside the buck converter take time until it charges and comes to the desired value. But since that the system will work continuously, the inductor and the capacitor will always be charged with a certain amount, so it will not take that much time to settle.

By ignoring the time problem and looking at the final value where the system settles, it is observed that the system can catch the desired value with an error ratio of less than $0.25 \%$, which can be considered as a neglectable value.

\subsection{Results of PVS Connected to MPPT With P\&O Algorithm}

In MATLAB PV array-based system, the algorithm is worked perfectly in the power section since all the obtained values are the same as those in the datasheet. In the time section, the results are not that good since, at every change, it takes the system more than $100 \mathrm{~ms}$ to reach the MPP.

In the designed system, the system could not catch the MPP in some cases, but in the worst case, the loss is not more than $1 \mathrm{~W}$, so it can be considered reasonable. In the time section, the system response is very late since the slightest change in irradiance makes the system more than $250 \mathrm{~ms}$ to settle at the MPP and compared to the MATLAB PV array-based system, it consumes double the time to settle. This time problem should be solved to increase the efficiency of the device.

\subsection{Results of PV Simulator Connected to MPPT With Modified P\&O Algorithm}

After modifying the algorithm, the step size of the duty cycle is set to be variable. Every system has its properties, so every system tested with various values of $\mathrm{dD}$ and every value of $\mathrm{dD}$ makes the system work differently, some of them made the system

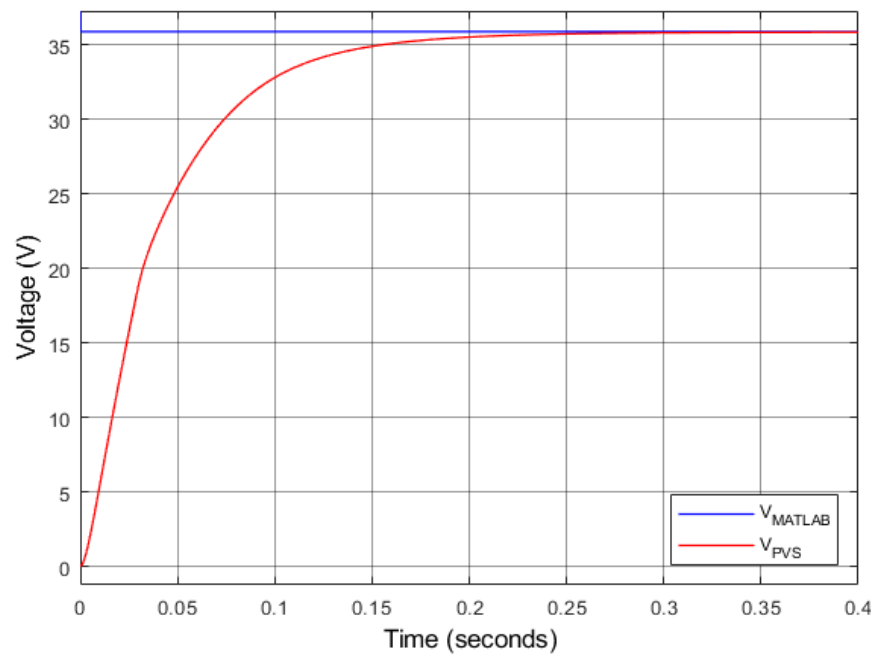

(a)

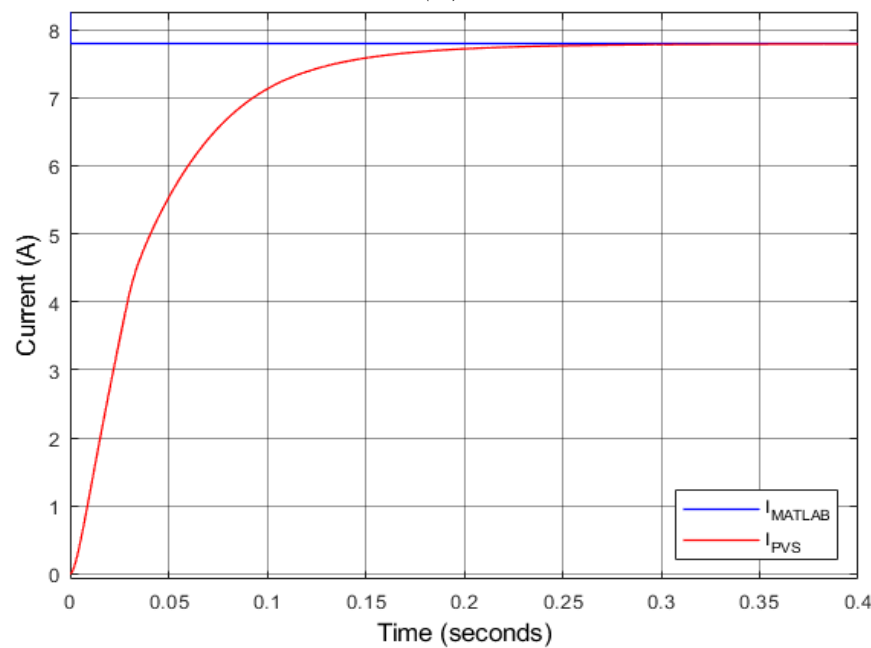

(b)

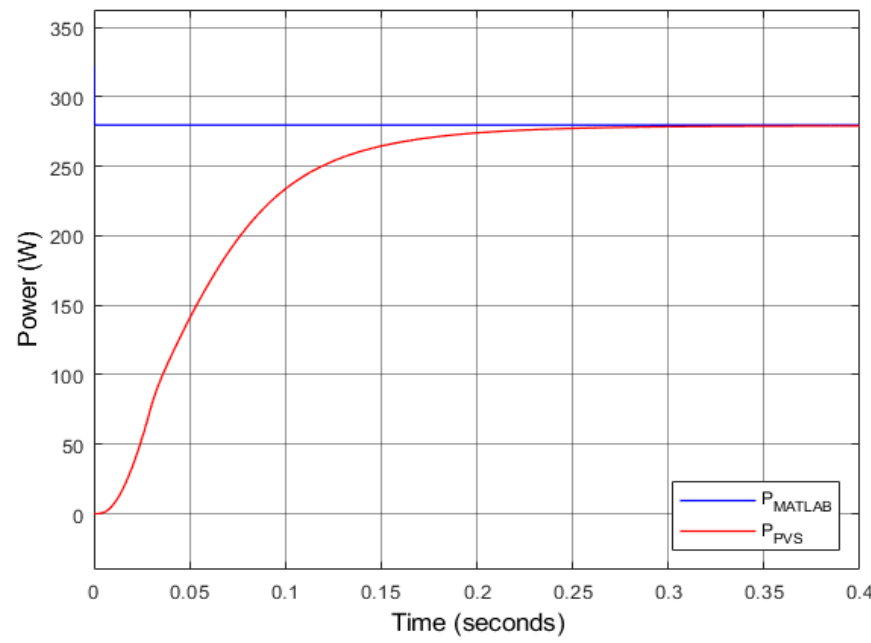

(c)

Fig. 7 MATLAB and PVS a) Voltage Results, b) Current Results, c) Power Results

stable, and others caused some errors. So, the values which provide the best performance were selected.

In MATLAB PV array-based system, excellent results are showing up after the modification. There were approximately no losses in power, and the time needed to reach the MPP is minimal in most cases. 
In the designed system, the system does not catch the exact MPP, and there were approximately $1 \mathrm{~W}$ of loss when the irradiance decreased. Still, this loss showed to be eliminated when the irradiance increases. The new algorithm partially solved the time problem faced in the typical algorithm since the time needed to reach the MPP is decreased by more than a half. All results mentioned B and C subsections could be seen in Fig. 8 and Fig. 9.

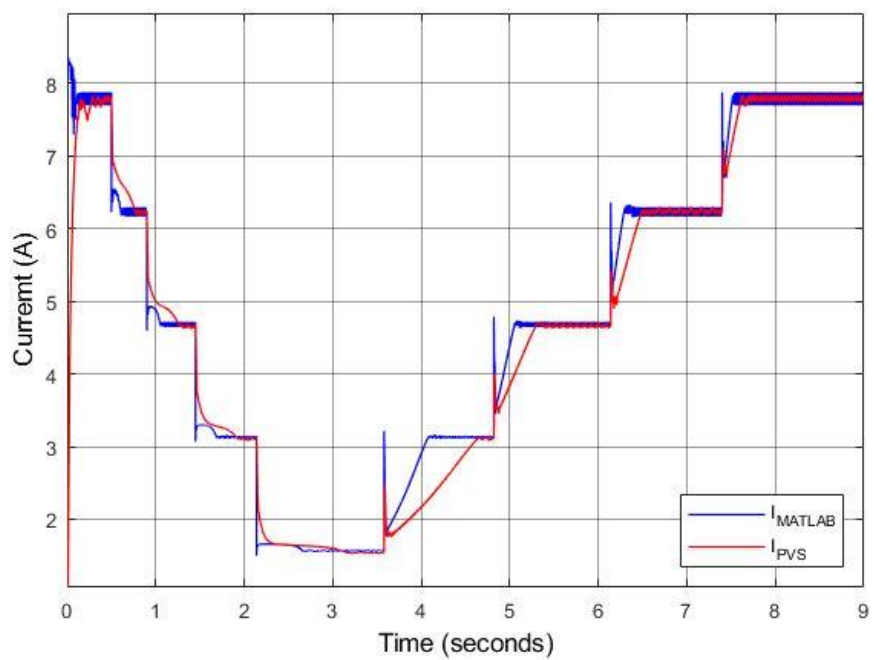

(a)

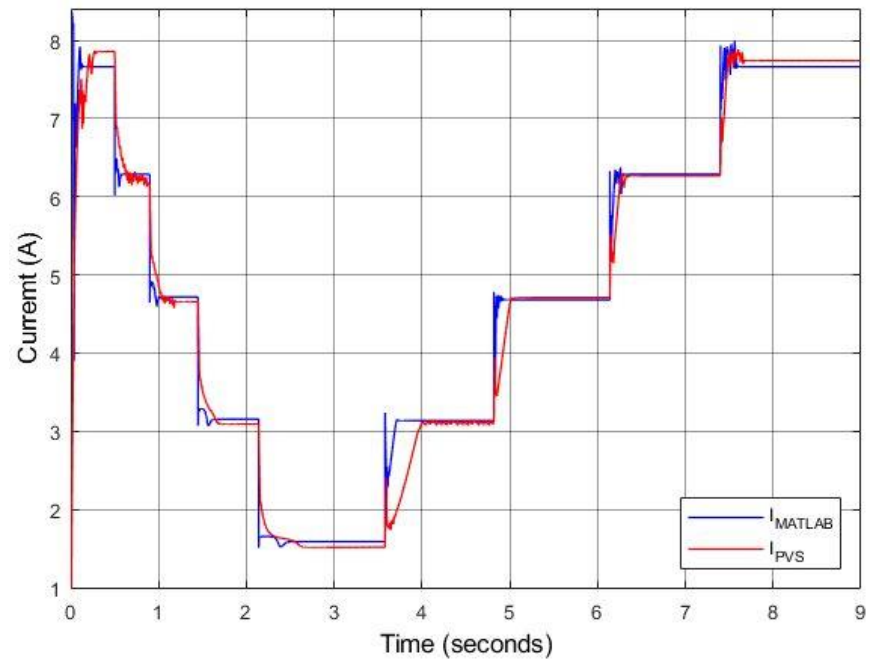

(b)

Fig. 8 Current graph of the a) $P \& O$, b) Modified $P \& O$

\subsection{DISCUSSION}

In this research, a low cost high efficient PVS is designed. The designed PVS shows high efficiency even in the changing irradiance. For more advanced tests, the MPPT algorithm is developed and connected to the system. The PVS has shown promising results using the $\mathrm{P} \& \mathrm{O}$ method. To give better results, the algorithm is modified, and the efficiency increases more than two times. A comparison between the behaviour of the systems before and after modifying the algorithm is presented with the graphics in Fig. 8 and Fig. 9. The advantages and disadvantages of the modified algorithm can be summarized shown in Table 4.

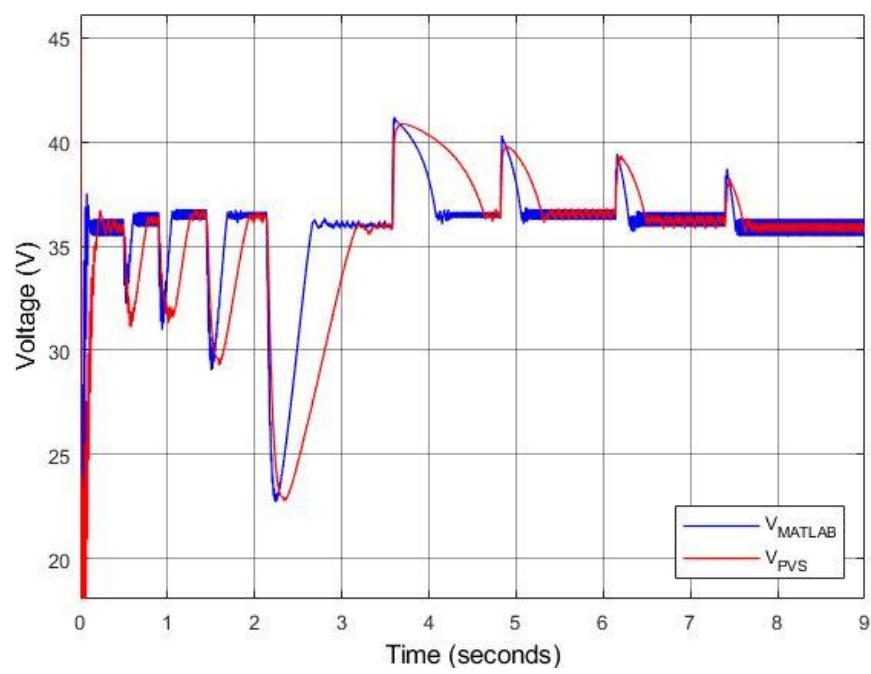

(a)

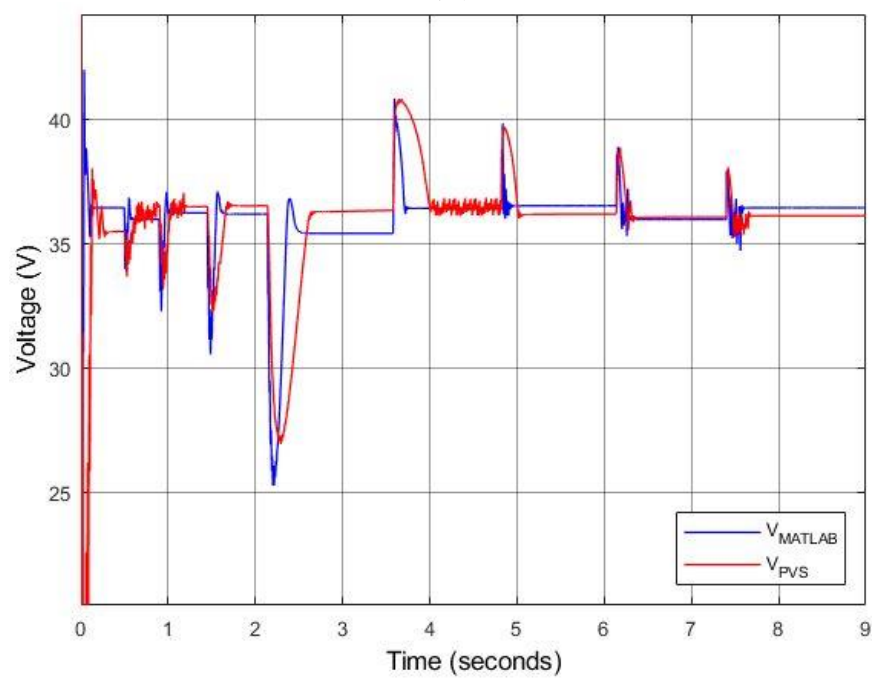

(b)

Fig. 9 Voltage graph of the a) $P \& O$, b) Modified $P \& O$

Table 4: Advantages and Disadvantages of the Modified Algorithm

\begin{tabular}{c|c}
\hline Advantages & Disadvantages \\
\hline Reach the MPP quickly & $\begin{array}{c}\text { Can not stop the ripple in } \\
\text { some cases }\end{array}$ \\
\hline $\begin{array}{c}\text { Stabilizes when it reaches } \\
\text { the MPP which stops }\end{array}$ & $\begin{array}{c}\text { False estimation of the MPP } \\
\text { in some cases } \\
\text { rippling and stops putting } \\
\text { press on electronic elements }\end{array}$ \\
\hline
\end{tabular}

\section{Conclusions and Recommendations}

This work is segmented into two parts: designing the simulator and testing it by connecting it to MPPT. The system can be designed with simple electronic circuits like Buck Converter, Op-amps, and microcontrollers. The designed simulator gave very satisfying results in a lot of cases.

$\mathrm{P} \& \mathrm{O}$ method is tested with the PVS, and it is worked without any problems. The classic $\mathrm{P} \& \mathrm{O}$ method is modified, and the efficiency increased by more than $50 \%$ for the PVS. 


\section{References}

Abdel-Salam, M., El-Mohandes, M. T., \& El-Ghazaly, M. (2020). An Efficient Tracking of MPP in PV Systems Using a Newly-Formulated P\&O-MPPT Method Under Varying Irradiation Levels. Journal of Electrical Engineering and Technology, 15(1), 501-513.

Ahmad, T., Sobhan, S., \& Nayan, Md. F. (2016). Comparative Analysis between Single Diode and Double Diode Model of PV Cell: Concentrate Different Parameters Effect on Its Efficiency. Journal of Power and Energy Engineering, 04(03), 31-46.

Amrouche, B., Belhamel, M., \& Guessoum, A. (2007). Artificial intelligence based P\&O MPPT method for photovoltaic systems.

Berrera, M., Dolara, A., Faranda, R., \& Leva, S. (2009). Experimental test of seven widely-adopted MPPT algorithms. IEEE Bucharest Power Tech Conference.

Boukezata, B., Chaoui, A., Gaubert, J. P., \& Hachemi, M. (2016). An improved fuzzy logic control MPPT based P\&O method to solve fast irradiation change problem. Journal of Renewable and Sustainable Energy, 8(4).

Delihasanlar, E., Yaylac1, E. K., \& Dalcalı, A. (2019). Dünyada ve Türkiye'de Güneş Enerjisi Potansiyeli, Mevcut Durumu, Teşvikleri, Kurulum Maliyeti Analizi-Karabük İli Örneği. Electronic Letters on Science \& Engineering, 15(1), 12-20.

Duc, H. N., Takano, H., Nguyen-Duc, T., Nguyen-Duc, H., \& LeViet, T. (2020). Single-Diode Models of PV Modules: A Comparison of Conventional Approaches and Proposal of a Novel Model. Energies.

Elgendy, M. A., Zahawi, B., \& Atkinson, D. J. (2012). Evaluation of perturb and observe MPPT algorithm implementation techniques. IET Conference Publications, 2012 (592 CP).

Ettappan, M., Maheswaran, G., Vimala, V., Somasundaram, K., \& Vishnupriyan, J. (2021). Design of Buck Converter and PV Module for Solar Powered Sailing Boat. Journal of Physics: Conference Series, 012023.

Farhat, M., Barambones, O., \& Sbita, L. (2016). A Real-Time Implementation of MPPT-Based on P\&O Method. IEEE.

Hart, D. (2010). Power Electronics. McGraw-Hill Education.

Kazimierczuk, M. K. (2008). Pulse-width Modulated DC-DC Power Converters.

Motahhir, S., el Hammoumi, A., \& el Ghzizal, A. (2020). The most used MPPT algorithms: Review and the suitable lowcost embedded board for each algorithm. In Journal of Cleaner Production. Elsevier Ltd.

Osmani, K., Haddad, A., Lemenand, T., Castanier, B., \& Ramadan, M. (2021). An investigation on maximum power extraction algorithms from PV systems with corresponding DC-DC converters. ELSEVIER.

Palanisamy, R., Vijayakumar, K., Venkatachalam, V., Narayanan, R. M., Saravanakumar, D., \& Saravanan, K. (2019). Simulation of various DC-DC converters for photovoltaic system. International Journal of Electrical and Computer Engineering (IJECE), 9(2), 917.

Rasheed, M., Mohammed, O. Y., Shihab, S., \& Al-Adili, A. (2021). A comparative Analysis of PV Cell Mathematical Model. Journal of Physics: Conference Series, 1795(1).

S. Hiwale, A., V.Patil, M., \& Vinchurkar, H. (2014). An Efficient MPPT Solar Charge Controller. International Journal of Advanced Research in Electrical, Electronics and Instrumentation Engineering, 3(7), 10505-10511.
Tamrakar, V., S.C, G., \& Sawle, Y. (2015). Single-Diode Pv Cell Modeling And Study Of Characteristics Of Single And Two-Diode Equivalent Circuit. Electrical and Electronics Engineering: An International Journal, 4(3), 13-24.

Tsuno, Y., Kamisako, K., \& Kurokawa, K. (2008). New Generation of PV Module Rating by LED Solar Simulator A Novel Approach and Its Capabilities.

Watjanatepin, N., \& Sritanauthaikorn, P. (2021). Large Scale LED-Modular-Based Solar Simulator and Calibration Method for PV-Module Characterization. Journal of Hunan University (Natural Sciences) , 48(9).

Yaqoob, S. J., Saleh, A. L., Motahhir, S., Agyekum, E. B., Nayyar, A., \& Qureshi, B. (2021). Comparative study with practical validation of photovoltaic monocrystalline module for single and double diode models. Scientific Reports, 11(1). 